\title{
PROPERTIES AND REFINEMENTS OF ACZÉL-TYPE INEQUALITIES
}

\section{JingFENG TIAN AND Ming-HU HA}

Abstract. In this paper, we present some new properties of Aczél-type inequalities, and then we obtain some new refinements of Aczél-type inequalities.

Mathematics subject classification (2010): Primary 26D15, secondary 26D10. Keywords and phrases: Aczél-type inequality, refinement, property.

\section{REFERENCES}

[1] J. ACZÉL, Some general methods in the theory of functional equations in one variable, New applications of functional equations, Uspehi. Mat. Nauk (N. S.) 11, 3 (1956), 3-68 (in Russian).

[2] M. BJELICA, On inequalities for indefinite form, Anal. Numer. Theor. Approx. 19, 2 (1990), 105-109.

[3] T. Popoviciu, On an inequality, Gaz. Mat. Fiz. Ser. A 11, 64 (1959), 451-461 (in Romanian).

[4] F. Qi, P. Cerone, S. S. Dragomir, H. M. SRivastava, Alternative proofs for monotonic and logarithmically convex properties of one-parameter mean values, Appl. Math. Comput. 208, 1 (2009), 129-133.

[5] J. Tian, Reversed version of a generalized Aczél's inequality and its application, J. Inequal. Appl. 2012, 2012: 202.

[6] J.-F. Tian, M.-H. HA, Properties of generalized sharp Hölder's inequalities, J. Math. Inequal. 11, 2 (2017), 511-525.

[7] J.-F. Tian, M.-H. Ha, Some new properties of generalized Hölder's inequalities, J. Nonlinear Sci. Appl. 9, 6 (2016), 3638-3646.

[8] J. Tian, Y. Zhou, Note on Aczél-type inequality and Bellman-type inequality, J. Nonlinear Sci. Appl. 9, 3 (2016), 1316-1322.

[9] P. M. VASIĆ, J. E. PEČARIĆ, On Hölder and some related inequalities, Mathematica Rev. D’Anal. Num. Th. L'Approx. 25 (1982), 95-103.

[10] P. M. VAsić, J. E. PeČARIĆ, On the Jensen inequality for monotone functions, An. Univ. Timişoara Ser. Şt. Matematice 17, 1 (1979), 95-104. 